\title{
Mathematical thinking ability of informatics students based on gender in calculus course
}

\author{
Triana Harmini ${ }^{1}$, Aziz Musthofa ${ }^{2}$, Shoffin Nahwa Utama ${ }^{3}$ \\ ${ }^{1,2,3}$ Universitas Darussalam Gontor, Jl. Raya Siman KM 6 Ponorogo, Indonesia
}

\begin{tabular}{l}
\hline A R T I C L E I N F O \\
Original Article \\
doi:10.18860/ijtlm.v2i1.8337 \\
\hline Keywords: \\
$\begin{array}{l}\text { Mathematical thinking, gender } \\
\text { differences, Calculus problem }\end{array}$
\end{tabular}

\begin{abstract}
A B S T R A C T
This study aimed to analyse the difference in the mathematical thinking abilities of Informatics Engineering students based on gender in Calculus problem-solving. Mathematical thinking ability was measured based on four indicators of the mathematical thinking process, namely specialisation, generalising, conjecturing, and convincing. The instruments in this study were mathematical thinking tests and observation sheets. The test used in this study was composed of four questions by indicators of the mathematical thinking process. The technique of data collection was the test, observation, and interview. Subjects of this study consisted of 35 male students and 22 female students. Data were analysed using the t-test. The results of the analysis showed that there is a significant difference in the mathematical thinking ability of male and female students. Mathematical thinking abilities of female students reached indicators of specialisation, generalising, and conjecturing. On the other hand, mathematical thinking abilities of male students passed the elements of speciality and generalising.
\end{abstract}

(C) 2019 IJTLM. All rights reserved.

*Corresponding author.

E-mail: triana@ unida.gontor.ac.id

How to cite: Harmini, T., Musthofa, A., \& Utama, S. N. (2019). Mathematical thinking ability of informatics students based on gender in calculus course. International Journal on Teaching and Learning Mathematics, 2(1), 7-14.

\section{INTRODUCTION}

Information technology has developed very fast, along with the development of science. Mathematics is one of the sciences that greatly influence the development of technology. Mastery of mathematics is a crucial thing for all students starting from elementary school level to college. At the college level, mathematics is the primary subject, especially in the Informatics department. Mathematics provides skills in abstraction, problem analysis and logical reasoning. Mathematics is a knowledge that contains proof, generalisation, application and unique characteristics that can help develop the nation's character (Toheri \& Winarso, 2017). Mathematics is taught to provide students with the ability to think logically, analytically, systematically, critically, and creatively as well as the ability to work together (Sukmadewi, 2014). Mathematics becomes the basics in designing information design, making software, web design and various other fields in the informatics department. Therefore mathematics is essentialfor learning and mastering the field of informatics.

In the informatics department, to make software or other programs that will require calculations and logical and mathematical. Mathematics is one of the vital knowledge in developing a mindset (Durandt \& Jacobs, 2018; Onal, Inan, \& Bozkurt, 2017; Westenskow, 
Moyer-Packenham, \& Child, 2017). Mathematics material that is studied in the informatics department is not only counting techniques but is more emphasized in the way of thinking will be very useful for informatics students.

Calculus is one of the courses that must be taken by students of the Informatics Engineering study program at the UniversitasDarussalam Gontor. This course studies about limits, derivatives, integrals and infinite series. In Calculus learning, students learn to solve complex problems using mathematical logic. By studying calculus students will more readily associate mathematical concepts in issue solving. Calculus learning includes a proof, generalisation, and application that can help develop students' mathematical thinking skills. Calculus can be used as a tool to be able to facilitate learning mathematics and other subjects.

Mathematical thinking ability can be interpreted as a thought process that involves the ability to collect, analyse and infer information to develop new understanding and knowledge (Nickerson, Lamb, \& LaRochelle, 2017; Layyina, 2018; Stein, Grover, \& Henningsen, 1996). Learning to think mathematically means learning to create a point of view of mathematics, which is to assess the process of abstraction in mathematics and try to apply it in problemsolving and develop competencies by using traits in mathematics (abstract, symbolic representation and symbolic manipulation) and use it to understand the structure and sense in mathematics (Schoenfeld, 2016). Mathematical thinking is not only realised in the form of numbers and abstract mathematical concepts but can be accomplished in everyday life (Onal et al., 2017). The development of the thought process is significant to be developed optimally and effectively as one of the provisions and abilities of students to face reality and challenges of future life (Fajri, 2017). Mathematical thinking can provide the ability to solve mathematical problems and the skills needed in independent learning (Lee, Ng, \& Bull, 2018; Rahman \& Rizkyanti, 2016). Mathematical thinking is the main target in learning mathematics (Nepal, 2017; Stockero, Rupnow, \& Pascoe, 2017). Teachers must focus on developing students' mathematical thinking skills through learning activities that can improve mathematics achievement (Nepal, 2016).

Mathematical thinking can be improved through the practice of solving questions or problems, reflecting on the experience, studying the problem-solving process and linking something that has been learned by personal experience (Sabri, 2009). Mathematical thinking is a very complex activity. Being able to use mathematical thinking in problem-solving is one of the main objectives of learning mathematics. There are four indicators of mathematical thinking processes, namely (1) Specialization - trying special cases by looking at examples, (2) generalizing - looking for patterns and relationships, (3) conjecturing - predicting relationships and outcomes, (4) Convincing - finding and communicating reasons why that is true (Stacey, 2006).

Universitas Darussalam Gontor is a pesantren-based university where all students are required to live in a dormitory. All student activities are well organised and conducive. Because the pesantren-based university, the male and female student hostel is $100 \mathrm{~km}$ away. Male students study and live at the central campus in Siman District, Ponorogo Regency. While female students study and live on campus II in the Mantingan District, Ngawi Regency. This is intended to maintain the climate of the pesantren that has been built at Pondok Modern Darussalam Gontor

Gender differences lead to differences in ways of thinking and ways of learning. According to Puspitawati, gender can be interpreted as differences in the roles, functions, status and responsibilities of men and women as a result of sociocultural construction through the process 
of socialising essence one generation to the next (Puspitawati, 2012). Biological differences between male and female cause hormonal differences that result in different treatments. This can develop into differences in abilities between male and female. According to Salmina in her research stated that female mathematical knowledge is better than male mathematical ability because most male students tend to be less careful, less accurate, and less confident in completing test questions (Salmina \& Nisa, 2018). Other research shows that gender differences influence the achievement of students' mathematical creative thinking abilities (Dilla, Hidayat, \& Rohaeti, 2018).

Based on the description, the purpose of this study is to analyse differences in mathematical thinking abilities of Informatics Engineering students by sex in solving Calculus problems. This study aimed to analyse the difference in the mathematical thinking abilities of Informatics Engineering students based on gender in Calculus problem-solving. Student mathematical ability is measured based on four indicators of mathematical thinking processes, namely specialisation, generalising, conjecturing, and convincing.

\section{METHOD}

The research method used is a combination of quantitative and qualitative research. The subjects in this study were students of the informatics department who took Calculus courses. The study was conducted at the Universitas Darussalam Gontor. The research subjects were 35 male students and 22 female students. Data collection methods use tests, observations, and interviews. The research instrument used in the form of analyses of mathematical thinking ability and observation sheets.

Mathematical thinking ability test is used to measure differences in mathematical thinking ability of male and female students and to analyse the level of mathematical thinking ability in male and female students. The test is in the form of a description of the questions that has 4 questions by indicators of the mathematical thinking process that is specialised, generalising, projecting, and convincing. The test questions used in this study were previously validated by 2 mathematics lecturers to determine the suitability of the test questions with indicators of mathematical thinking processes. The validation results show that the test questions are by indicators of the mathematical thinking process and can be used to measure students' mathematical thinking abilities. Observation sheets are used during the learning process based on four signs of the mathematical thinking process. Observations made on observations of the lecturer learning process. Indicators of the mathematical thinking process used in this study are presented in Table 1.

Table 1. Indicators of students' mathematical thinking process

\begin{tabular}{lcl}
\hline No & Aspect & \\
\hline 1 & Specialising & - Able to identify and determine questions \\
& & - Able to decide on the concepts used to solve problems \\
& & - Able to solve routine problems according to the example \\
& Generalising & - Able to determine patterns and conceptual relationships \\
& & - Able to explain the concepts used \\
& & - Able to connect ideas with what is already known \\
& Conjecturing & - Able to conclude correctly \\
& & - Able to predict the relationship between concepts \\
4 & Convincing & - Being able to determine the results correctly \\
& & - Able to account for results \\
& & Able to find and communicate the reasons why something is true \\
\hline
\end{tabular}


Data analysis was carried out quantitatively and qualitatively. Quantitative analysis was conducted to determine differences in mathematical thinking abilities of male and female students. Quantitative analysis based on the results of tests of mathematical thinking ability. Data analysis using t-test (independent sample) with analysis prerequisites in the form of normality and homogeneity tests. Test analysis utilizing the help of IBM SPSS Statistics 20. Qualitative analysis is used to analyse the ability of mathematical thinking of male and female students. The qualitative analysis based on test results, observations, and interviews. For the interview process, random samples were taken each of 3 male students and three female students

\section{RESULTS ANDDISCUSSION}

The results of the study are in the form of data on the results of tests of mathematical thinking ability, observations and interview results. Observations were made during the implementation of Calculus learning to determine student activities during learning based on four indicators of the mathematical thinking process. The observation was carried out by 2 observers. The results of observations on male students show that during the learning process male students in completing exercises or student activities tend to lack confidence and only follow their friends in answering questions. Students tend to answer the questions as they are by the examples that have been discussed without further efforts to solve them. Male students are able to know the problems that exist in the problem and know the concepts that must be used in solving them. This shows that male students can think mathematically in the aspects of specialisation and generalisation.

The results of observations on female students show that female students are more active during the Calculus learning process. Girls students can solve practice questions according to the examples given and can find patterns of relationships between concepts to solve problems. Girls students tend to be able to explain the issues that exist in the challenge and be able to tell the concepts used to solve the problem. During learning, female students tend to be more eager to answer all lecturer questions and ask more about the relationships between concepts in Calculus. This shows that female students have mathematical thinking abilities that meet the aspects of specialisation, generalising, and conjecturing.

Data on the results of tests of students' mathematical thinking ability in the form of test scores in the Calculus course. Overall the results of tests of mathematical thinking ability of male and female students there are differences in the average value. A summary of the results of a student's mathematical thinking ability test is presented in Table 2 .

Table 2. Summary of descriptive analysis of student mathematical thinking ability test results

\begin{tabular}{ccc}
\hline Statistics & $\begin{array}{c}\text { Mathematical thinking Ability of } \\
\text { Male's Students }\end{array}$ & $\begin{array}{c}\text { Mathematical thinking Ability of } \\
\text { Female's Students }\end{array}$ \\
\hline Average & 61,08 & 70,41 \\
Deviation Standards & 16.61 & 11.62 \\
Minimum & 90 & 94 \\
Maximum & 34 & 53 \\
\hline
\end{tabular}

From Table 2 it can be seen that the average score of the female students mathematical thinking ability tests is better than the average results of the male students' mathematical thinking ability test. This means that there are differences in mathematical thinking abilities of male and female students. To find out the significance of the differences in mathematical thinking abilities of male and female students a statistical test was performed using the t-test. 
Formally the statistical hypothesis (Ho) and research hypothesis (H1) are as follows:

Ho: There is no significant difference in the mathematical thinking ability of male and female students

$\mathrm{H} 1$ : there is a significant difference in the mathematical thinking ability of male and female students

Hypothesis testing criteria namely $\mathrm{H} 0$ is rejected if $\mathrm{t}$-count $<\mathrm{t}$-table or $\mathrm{t}$ count $<\mathrm{t}$-table or $\mathrm{p}$ value (Sig) $<0.025$. The analysis prerequisite test for the $t$-test is normality and homogeneity test. The normality test for both data was carried out by the Kolmogorov-Smirnov test with the test criteria that the data were normally distributed if the p-value (Sig) $<0.05$. A summary of the results of the normality test using IBM SPSS Statistics 20 is presented in Table 3.

Table 3.Summary of normality test results

\begin{tabular}{cccc}
\hline & \multicolumn{3}{c}{ Kolmogorov-Smirnov $^{\mathrm{a}}$} \\
& Statistic & df & Sig. \\
\hline Male & .100 & 35 & .200 \\
Female & .134 & 22 & .200 \\
\hline
\end{tabular}

From Table 3 it can be seen that the data of mathematical thinking ability of male students Sig value of $0.200>0.05$ which means the data on mathematical thinking ability of male students is normally distributed. In the data of female students mathematical thinking ability, the Sig value is $0.200>0.05$, which means that the female students' mathematical thinking ability data is normally distributed. Analysis prerequisites for the normal distribution are met. Because both data are independent, the data must achieve homogeneity. Homogeneity test data is done by Levene test with the test criteria that the information is said to be homogeneous if the Sig value $>0.05$. A summary of the homogeneity test results is presented in Table 4.

Table 4. Summary of homogeneity test

\begin{tabular}{rrrr}
\hline Levene Statistic & df1 & df2 & Sig. \\
\hline 3.745 & 1 & 55 & .058 \\
\hline
\end{tabular}

From Table 4 it can be seen that the Sig value is $0.058>0.05$ which means that the two data are homogeneous. From the results of normality and homogeneity tests, it is known that the data have fulfilled the analysis prerequisites for the t-test. Furthermore, hypothesis testing is performed to determine the significance of the difference in the average results of mathematical thinking abilities of male and female students. Analyses were performed using the t-test (independent sample). A summary of the results of the t-test is presented in Table 5.

Table 5. Summary of t-test

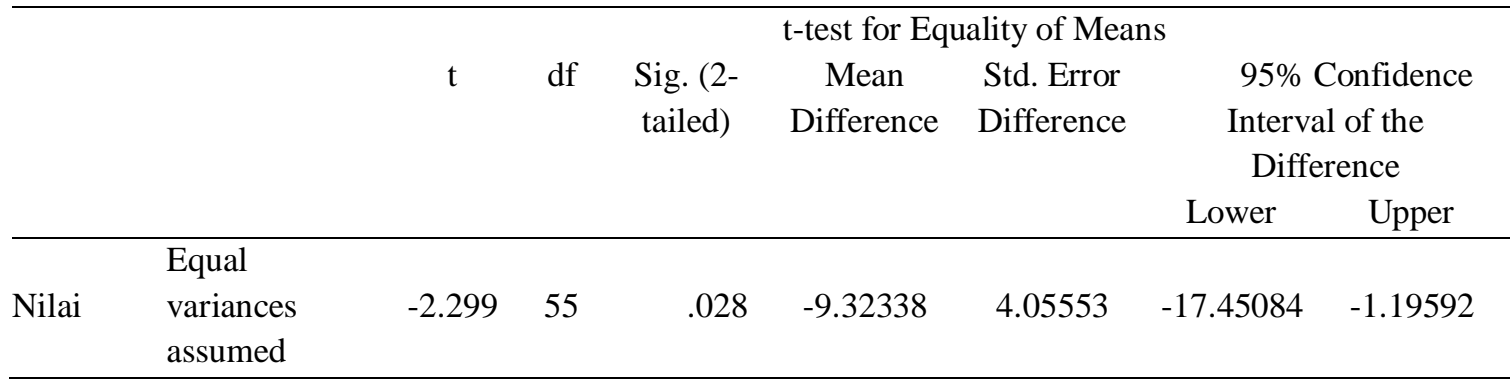

Based on the test results in Table 5, it is known that the Sig value of $0.028<0.025$, it can be concluded that $\mathrm{Ho}$ is rejected and $\mathrm{H} 1$ is accepted. This means that there are significant differences in the mathematical thinking ability of male and female students. From the results of 
the average mathematical thinking ability of female students is higher than the average mathematical thinking ability of male students. It can be concluded that the results of female students thinking abilities are better than the male students' mathematical thinking abilities.

Male and female students have differences in learning attitudes. Females students use more learning strategies compared to male students. In terms of learning, female students are more diligent and prefer to have discussions with friends. Female students have better communication skills than male students. This is consistent with the results of Nugraha and Pujiastuti's research which states that overall female has better mathematical communication skills than male (Nugraha \& Pujiastuti, 2019). Females can respond to the teacher's verbal communication and use problem-solving strategies(Klein, Adi-Japha, \& Hakak-Benizri, 2010). Male students tend to be less thorough and not coherent in solving problems, but male students have logical thinking patterns in explaining and solving problems. Male students tend to be careless in completing the final results, so the test results tend to be lower. This is because male students are less coherent in solving problems, so the final results often get errors.

The results of interviews with three male student samples show that male students tend to be less interested in learning mathematics. This causes students to tend only to be able to follow the completion by the examples given, less thorough and careful in solving problems so that the results of tests for male students mathematical thinking abilities are lower than their students' mathematical thinking abilities. Male students tend to be logical and rational. According to Stacey, if students can think mathematically meaning students will tend to do something mathematically and have a reasonable attitude (Stacey, 2006). Male students are also able to find information that is interconnected correctly, able to conduct analyses to determine the concepts used in problem-solving. Besides that, male students are also able to connect the concepts they have learned to solve the problems. This shows that male students tend to have the ability to think mathematically in the aspects of specialisation and generalisation.

Interviews with three female students revealed that the female students had a well-organised and organised mindset and were able to solve problems gradually through a precise method. This is in line with the findings of Khairina, Pujiastuti and Loving who say that women are better at solving problems, writing mathematical methods and symbols, and giving solving ideas (Khairina, Pujiastuti, \& Asih, 2018). Female students are also able to explain complete procedures in solving problems. Female students have higher self-confidence and interest compared to male students in learning mathematics so that in working on issues, female students are more careful and thorough. This causes the results of tests of mathematical thinking ability of female students is better than the results of tests of the thinking ability of female students. From the results of this interview, it can be concluded that female students can think mathematically in the aspects of specialisation, generalising, and conjecturing.

The ability to think mathematically is not only related to theoretical concepts in the classroom but more emphasis on developing the ability to apply and implement concepts in various circumstances in the field so that learning becomes meaningful for students. The mathematical thinking process contributes a lot to the development of thinking in optimizing the capacity and capability of thinking of learning participants (Fajri, 2017). Female students tend to have logical thinking patterns in solving problems in calculus. Female have better values than male in the aspects of using symbols, thinking logically, and systematically (Mubark, 2012). The ability to think mathematically provides a very large role in developing the potential of students, especially in the Informatics Engineering study program. Mathematical thinking skills can be improved through learning based on the practice of solving problems. In solving 
problems, students are required to think logically, coherently and effectively, so they can solve Calculus problems correctly.

\section{CONCLUSION}

This study showed that there were significant differences in the mathematical thinking ability of female and male students. From the results of the average test scores of students' mathematical thinking ability, it can be seen that the mathematical thinking ability of female students is better than the mathematical thinking ability of male students. From the results of observations and interviews, it can be seen that male students tend to have the ability to think mathematically in the aspects of specialisation and generalising and female students have the ability to think mathematically in the elements of specialization, generalizing, and conjecturing. Male students can identify and determine questions, can decide on the concepts used to solve problems, and can solve routine problems according to the example. Female students can draw conclusions correctly, can predict relationships between ideas, and can determine outcomes accurately.

\section{REFERENCES}

Dilla, S. C., Hidayat, W., \& Rohaeti, E. E. (2018). Faktor gender dan resiliensi dalam pencapaian kemampuan berpikir kreatif matematis siswa SMA. Journal of Medives: Journal of Mathematics Education IKIP Veteran Semarang, 2(1), 129-136. https://doi.org/10.31331/medives.v2i1.553

Durandt, R., \& Jacobs, G. J. (2018). Exploring the initial convictions and mindset of prospective mathematics teachers towards modelling. In Educating Prospective Secondary Mathematics Teachers (pp. 307-324). Springer, Cham.

Fajri, M. (2017). Kemampuan Berpikir matematis dalam konteks pembelajaran abad 21 di sekolah dasar. jurnal LEMMA, 3(1), 1-11. https://doi.org/10.22202/j1.2017.v3i1.1884

Khairina, I., Pujiastuti, E., \& Asih, T. S. N. (2018). The mathematical communication ability based on gender difference on students of 11th grade by using problem-based learning model assisted by probing prompting technique. Unnes Journal of Mathematics Education, 7(2), 78-84. https://doi.org/10.15294/ujme.v7i2.20645

Klein, P. S., Adi-Japha, E., \& Hakak-Benizri, S. (2010). Mathematical thinking of kindergarten boys and girls: Similar achievement, different contributing processes. Educational Studies in Mathematics, 73(3), 233-246. https://doi.org/10.1007/s10649-009-9216-y

Layyina, U. (2018). Analisis kemampuan berpikir matematis berdasarkan tipe kepribadian pada Model 4K dengan asesmen proyek bagi siswa Kelas VII. In PRISMA, Prosiding Seminar Nasional Matematika (Vol. 1, pp. 704-713).

Lee, K., Ng, S. F., \& Bull, R. (2018). Learning and solving algebra word problems: The roles of relational skills, arithmetic, and executive functioning. Developmental Psychology, 54(9), 1758-1772. https://doi.org/10.1037/dev0000561

Mubark, M. (2012). Gender differences in mathematical thinking and mathematical achievement in Jordanian 6 th grade. International Journal of Arts \& Sciences, 5(2), 523533.

Nepal, B. (2016). Relationship between mathematical thinking and mathematics achievement. IOSR Journal of Research Mrthod in Education (IOSR-JRME), 6(6), 46-49. https://doi.org/10.9790/7388-0606044649

Nepal, B. (2017). Impact of Gender and location on mathematical thinking and mathematics achievement. Journal of Advanced Academic Research, 3(3), 11-21. https://doi.org/10.3126/jaar.v3i3.16803

Nickerson, S. D., Lamb, L., \& LaRochelle, R. (2017). Challenges in measuring secondary mathematics teachers' professional noticing of students' mathematical thinking. In Teacher noticing: Bridging and broadening perspectives, contexts, and frameworks (pp. 381-398). Springer, Cham. 
Nugraha, T. H., \& Pujiastuti, H. (2019). Analisis kemampuan komunikasi matematis siswa berdasarkan perbedaan gender. Edumatica: Jurnal Pendidikan Matematika, 9(1), 1-7. https://doi.org/10.22437/edumatica.v9i1.5880

Onal, H., Inan, M., \& Bozkurt, S. (2017). A Research on mathematical thinking skills: Mathematical thinking skills of athletes in individual and team sports. Journal of Education and Training Studies, 5(9), 133. https://doi.org/10.11114/jets.v5i9.2428

Puspitawati, H. (2012). Gender dan keluarga: Konsep dan realita di Indonesia. Bogor: PT IPB Press.

Rahman, Z. A., \& Rizkyanti, T. (2016). Kemampuan berpikir matematis siswa pada pembelajaran metode discovery learning dan metode ekspositori. Gammath, 1(1), 1-9. https://doi.org/http://dx.doi.org/10.32528/gammath.v1i1.418

Sabri. (2009). Berpikir matematis untuk pemahaman pada tingkat kesadaran. Review of Educational Research, 19(1), 1-11.

Salmina, M., \& Nisa, S. K. (2018). Kemampuan penalaran matematis siswa berdasarkan gender pada materi geometri. Jurnal Numeracy, 5(1), 41-48.

Schoenfeld, A. H. (2016). Learning to think mathematically: Problem solving, metacognition, and sense making in mathematics (Reprint). Journal of Education, 196(2), 1-38.

Stacey, K. (2006). What is mathematical thinking and why is it important? Paper presented at the Tsukuba International Conference 2007 "Innovative Teaching Mathematics through Lesson Study (II) "-Focusing on Mathematical Thinking, Tokyo \& Sapporo, Japan (pp. 39-48). Retrieved from http://earchives.criced.tsukuba.ac.jp/data/doc/pdf/2009/02/Kaye_Stacey.pdf

Stein, M. K., Grover, B. W., \& Henningsen, M. (1996). Building student capacity for mathematical thinking and reasoning: An analysis of mathematical tasks used in reform classrooms. American educational research journal, 33(2), 455-488.

Stockero, S. L., Rupnow, R. L., \& Pascoe, A. E. (2017). Learning to notice important student mathematical thinking in complex classroom interactions. Teaching and Teacher Education, 63, 384-395.

Sukmadewi, T. S. (2014). Improving students' mathematical thinking and disposition through probing and pushing questions. Jurnal Matematika Integratif, 10(2), 127-137. https://doi.org/10.24198/jmi.v10.n2.10255.127-138

Toheri, \& Winarso, W. (2017). Mathematical thinking undefended on the level of the semester for professional mathematics teacher candidates. Munich Personal RePEc Archive, (78486), 1-18. https://doi.org/10.6084/m9.figshare.4956371.v1

Westenskow, A., Moyer-Packenham, P. S., \& Child, B. (2017). An iceberg model for improving mathematical understanding and mindset or disposition: An individualized summer intervention program. Journal of Education, 197(1), 1-9. 